\title{
The concentration of optimum dissolved oxygen levels for growth of mangrove crab Scylla serrata seed in recirculation system
}

\author{
Konsentrasi oksigen terlarut optimum untuk pertumbuhan \\ benih kepiting bakau Scylla serrata dalam sistem resirkulasi
}

\author{
Kurnia Faturrohman, Kukuh Nirmala*, D. Djokosetiyanto , Yuni Puji Hastuti \\ Departemen Budidaya Perairan, Fakultas Perikanan dan Ilmu Kelautan, Institut Pertanian Bogor \\ Kampus IPB Dramaga Bogor, Jawa Barat 16680 \\ *E-mail: kukuhnirmala@yahoo.com
}

\begin{abstract}
This study aimed to determine optimum dissolved oxygen (DO) through the addition of aeration and to evaluate the role of dissolved oxygen on production performance and stress responses of mangrove crab Scylla serrata. Experimental design used was complete randomized design with four treatments namely no aeration (A), one point aeration (B), two points aeration (C), and three points aeration (D). All treatments replicated three times. The crab with the average of body weight $45.6 \pm 2.1 \mathrm{~g} /$ individual cultured in a plastic box $\left(40 \times 30 \times 30 \mathrm{~cm}^{3}\right)$. The stocking densities was $10 \mathrm{crab} / \mathrm{box}$. Crab was cultured within 42 days and were fed two times a day by restricted method (15\% of the total biomass). The result showed that $C$ treatment produced $5.51 \mathrm{mg} / \mathrm{L}$ dissolved oxygen and gave the best result of mangrove crabs production performance with $60 \%$ survival, $0.83 \pm 0.03 \mathrm{~g} /$ day absolute growth rate and food conversion ratio 1.1. It also showed good response to the stress that indicated by the cortisol level (10.159 $\mu \mathrm{g} / \mathrm{dL}$ ). The best results of coefficient of diversity showed by D treatment that was $13.5 \%$. The water quality during study period was fluctuative as affected by different dissolved oxygen value.
\end{abstract}

Keyword: mangrove crabs, dissolved oxygen, production performance

\begin{abstract}
ABSTRAK
Penelitian ini bertujuan menentukan kadar oksigen terlarut (OT) atau dissolved oxygen (DO) yang optimum melalui penentuan titik aerasi serta mengevalusi peranan oksigen terlarut terhadap kinerja produksi dan respons stres kepiting bakau Scylla serrata. Rancangan penelitian yang digunakan adalah rancangan acak lengkap dengan empat pelakuan (penambahan titik aerasi dengan rincian A, tidak menggunakan titik aerasi; $\mathrm{B}$, satu titik aerasi; $\mathrm{C}$, dua titik aerasi dan D, tiga titik aerasi) dan tiga ulangan. Kepiting bakau yang digunakan memiliki berat rata-rata 45,6 2 2,1 g/ekor dengan padat tebar 10 ekor/wadah. Wadah yang digunakan selama pemeliharaan adalah bak fiber plastik yang berukuran $40 \times 30 \times 30 \mathrm{~cm}^{3}$. Pemeliharaan kepiting bakau dilaksanakan selama 42 hari dan diberikan pakan dua kali sehari dengan metode restricted yakni sebesar 15\% dari biomassa kepiting. Hasil penelitian menunjukkan bahwa perlakuan $\mathrm{C}$ yaitu penambahan dua titik aerasi menghasilkan nilai kelarutan oksigen rata-rata sebesar $5,51 \mathrm{mg} / \mathrm{L}$ dan memberikan hasil terbaik terhadap kinerja produksi kepiting bakau (tingkat kelangsungan hidup 60\%; laju pertumbuhan mutlak 0,83 $\pm 0,03 \mathrm{~g} / \mathrm{hari}$; dan rasio konversi pakan 1,1). Perlakuan $\mathrm{C}$ juga menunjukkan respons stres yang baik dengan memiliki nilai kortisol paling rendah dari perlakuan lain yaitu $10,159 \mu \mathrm{g} / \mathrm{dL}$. Untuk parameter koefisien keragaman berat, hasil terbaik terjadi pada perlakuan D sebesar 23,3\%. Kualitas air selama penelitian memiliki nilai yang fluktuatif di setiap perlakuan sebagai efek adanya perbedaan nilai kelarutan oksigen yang dihasilkan.
\end{abstract}

Kata kunci: kepiting bakau, kelarutan oksigen, kinerja produksi

\section{INTRODUCTION}

Mud crab Scylla serrata is considered as a biological aquatic resource with a high economic value that has a good potential for farming. In addition, it is well appreciated by communities due to its nutritional value (Suprapto et al., 2014). Indeed, proximate analysis of mud crab demonstrated that it contained essential nutrients, such as protein $(47.31 \%)$ and fat $(11.20 \%)$ 
(Siahainenia, 2009). The increasing demand, especially on export markets, supported mud crab in becoming one of the mainstays for exportation (non-oil commodities) along with tiger prawns and was also classified among commodities with increasing production, reaching up to $188 \%$ in 2014 (Ministry of Marine Affairs and Fisheries Republic of Indonesia, 2010). However, this increasing demand for export is not supported by the crab population, since most of the produced crab still derived from natural catch, which is known to fluctuate. Based on the continuity of the production, there is an urgent need to develop a controllable mud crab production system, which is effective, efficient, and economically profitable and in accordance with the biological behavior of mud crab. In fact, mud crab could reach maximum growth through environmental manipulations.

Mud crab growth, as any other aquatic organism, depends on the excess of energy that remains after the energy demand for various important activities is fulfilled. Environmental changes are known to affect the amount of energy needed by the crab, which could be bigger or lower than the metabolized energy. Metabolism, which includes anabolism and catabolism, is defined as chemical reaction processes that take place in the body (Sousa et al., 2010). Oxygen consumption rate is a physiological parameter that can be used to indirectly estimate the metabolic rate by measuring the oxygen used in the oxidation process. Oxygen consumption rate in crustacean is influenced by both internal and external factors. Internal factors include species, stadia, weight, activity, sex, reproduction and molting, while external factors are strongly influenced by the environmental conditions such as salinity, $\mathrm{pH}$, temperature, dissolved oxygen, light, food, and carbon dioxide status (Paital \& Chainy, 2012). Previous research demonstrated that rearing mud crab in a recirculating system that meet the required external factors could reduce the burden of energy used by the crab to adapt to its environment, so that the excess of energy can be used for growth (Hastuti et al., 2016). The recirculation system used was aimed at minimizing water exchange process so that dissolved oxygen (DO) become an important parameter for water quality maintenance. The nitrification process, which is carried out by bacteria, could be a potential competitor for mud crab in terms dissolved oxygen, since bacteria require DO to assist in the breakdown of organic matters into simple compounds. Dissolved oxygen plays an important role in the metabolic processes (in mud crab) leading to energy production. Thus, the availability DO at an optimum level through specific aeration points is needed in order to support mud crab metabolic processes in a recirculating system.

The purpose of the present study was to determine the optimal dissolved oxygen (DO) level through aeration points and evaluate the role of dissolved oxygen in mud crab $S$. serrata production performance and stress response as well. The results were expected to be applied in mud crab farming and used as reference for further research using containers in a recirculating system.

\section{MATERIALS AND METHODS}

\section{Research design}

A completely randomized design with three treatments (three different stocking densities) was used in this study, consisting of 5 (P1), 10 (P2), and $15(\mathrm{P} 3) \mathrm{crab} / \mathrm{container}$. Each treatment was replicated three times.

\section{Preparation and preliminary test}

Thirty juvenile mud crabs $S$. serrata, brought from Jepara, Central Java, was used in the present study and stocked at a density of 30 crabs/ treatment. Each treatment was replicated three times, thus, the 30 crabs were divided between 3 containers (Fiber Box, $40 \times 60 \times 40 \mathrm{~cm}$ ) for each treatment. Juvenile crabs were stocked at average body weight, carapace length and width of $46.6 \pm 1.06 \mathrm{~g}, 8.0 \pm 0.4 \mathrm{~cm}$, and $4.6 \pm 0.2 \mathrm{~cm}$, respectively.

The preliminary test was conducted to determine the flow rate of aeration that should be provided at each aeration point in order to have a uniform air supply at each point. The first step was to find the oxygen requirement of a single crab through an oxygen consumption rate test (OCR), which can be used to calculate the total oxygen required for rearing 10 crabs. Inlets, in the recirculation system, were equipped with hose to the bottom of the container so that water rush, which is well known to affect DO, would be reduced during measurements. A level of oxygen consumption of $0.49 \mathrm{mgO} / \mathrm{g} / \mathrm{h}$ was obtained during the test above, which led to an estimated total required oxygen of $4.9 \mathrm{mg} / \mathrm{L} \mathrm{O}_{2}$ for 10 crabs (each container). Meanwhile the DO level of a container without aeration points was just $3.7 \mathrm{mg} / \mathrm{L} \mathrm{O}_{2}$. The difference between crab 
DO requirement and the DO present in rearing containers was used as reference for determining the flow rate of aeration needed for a single aeration point. The flow rate of aeration needed in fulfilling the $4.9 \mathrm{mg} / \mathrm{L} \mathrm{O}_{2}$ required for mud crab was $1 \mathrm{~L} / 8 \mathrm{~s}$ (or $0.125 \mathrm{~L} / \mathrm{s}$ ) for each aeration point.

Brackishwater was used in the present study. Seawater at a salinity of $35 \mathrm{~g} / \mathrm{L}$ was brought from Ancol, diluted in order to reach the optimum salinity $(25 \mathrm{~g} / \mathrm{L})$ for mud crab growth performance (Hastuti et al., 2013). Containers were prepared by creating a recirculation system for each treatment, aiming to maintain a stable environment in rearing containers so that water quality parameters remain within normal range and feces and feed residue accumulations could be reduced to a minimum. Three different filters were used i.e. biological, chemical, and physical. The physical filter consisted of cotton and sand layer, while the chemical filter was made of zeolith stone. Bioball were used as substrat for biological filter.

\section{Test crab maintenance}

Trash fish, brought from fish market (TPI) in Muara Angke, was used to feed the crabs, which were fed four times daily (at 08:00 am, 02:00 $\mathrm{pm}$, 08:00 pm, and 11:00 pm) using a restricted feeding method (10\% of crab biomass) (Suprapto et al., 2014). The recirculation system was closely monitored in order to maintain a stable water quality throughout the research. $5 \%$ of the rearing water was siphoned out on a daily basis to clean out feed residue. Tested parameters are presented in Table 1.

Water quality parameters such as temperature, $\mathrm{pH}$, and dissolved oxygen (DO) were recorded on a daily basis (at 08:00 am, 12:00 am, 05:00 pm, and 10:00 pm), while the other parameters like growth performance and oxygen consumption were measured weekly. Stress response (hemolymph cortisol) was measured at the beginning, and the end of the rearing period.

\section{Data analysis}

The data were analyzed and tabulated using Microsoft Excel 2007 and SPSS and presented in forms of tables and graphs. Analysis of variance (ANOVA) with $\mathrm{F}$ test at $95 \%$ of confidence interval was used to analyse data on production, while descriptive analysis was used for stress response and water quality profile.

\section{RESULTS AND DISCUSSION}

\section{Results}

Production performance

Production performance parameters, such as survival rate (SR), absolute growth rate (AGR), feed conversion ratio (FCR), and weight uniformity coefficient are presented in Table 2.

The analysis of variance (ANOVA) results

Table 1. Tested parameter

\begin{tabular}{llcc}
\hline & \multicolumn{1}{c}{ Parameter } & Unit & Measuring materials and methods \\
\hline \multirow{4}{*}{$\begin{array}{l}\text { Production } \\
\text { parameters }\end{array}$} & survival rate (SR) & $\%$ & Goddard (1996) \\
& absolute growth rate (AGR) & $\mathrm{g} / \mathrm{hari}$ & Goddard (1996) \\
& feed conversion ratio (FCR) & - & Goddard (1996) \\
& weight uniformity coefficient (UC) & $\%$ & Steel and Torrie (1993) \\
\hline \multirow{2}{*}{ Stress response } & oxygen consumption level & $\mathrm{mgO}_{2} / \mathrm{g} / \mathrm{jam}$ & Liao and Huang (1993) \\
& hemolymph cortisol level & $\mathrm{nmol} / \mathrm{L}$ & Blaxhall and Daysley (1973) \\
\hline \multirow{5}{*}{ Water quality } & $\mathrm{pH}$ & - & $\mathrm{pH}$ meter \\
& dissolved oxygen (DO) & $\mathrm{mg} / \mathrm{L}$ & DO meter \\
& temperature & ${ }^{\circ} \mathrm{C}$ & thermometer \\
& salinity & $\mathrm{g} / \mathrm{L}$ & salinometer \\
& total suspended solid (TSS) & $\mathrm{mg} / \mathrm{L}$ & titration \\
& ammonia & $\mathrm{mg} / \mathrm{L}$ & weighing machine \\
& nitrite & $\mathrm{mg} / \mathrm{L}$ & spectrophotometer \\
& nitrate & $\mathrm{mg} / \mathrm{L}$ & spectrophotometer \\
\hline
\end{tabular}


showed significant differences among treatments in terms of survival rate (SR), absolute growth rate (AGR), feed conversion ratio (FCR), and weight uniformity coefficient (WUC) $(\mathrm{P}>0.05)$. The highest SR, AGR, and WUC were observed in treatment C $(63.33 \pm 5.77 \%, 0.83 \pm 0.03 \mathrm{~g} / \mathrm{crab} / \mathrm{day}$, and $21.50 \pm 1.3 \%$, respectively) and the lowest in treatment D $(20 \pm 10 \%, 0.44 \pm 0.01 \mathrm{~g} / \mathrm{crab} /$ day, and $12.99 \pm 0.5 \%$, respectively). However, treatment $C$ had the lowest FCR $(3.6 \pm 0.2)$, while treatment D had the highest FCR $(6.9 \pm 0.6)$.

\section{Stress response}

Stress response included hemolymph cortisol level and oxygen consumption level (OC).

Hemolymph cortisol levels during the rearing period are presented in Figure 1 and increments were observed in all treatments. The lowest increment was noticed in treatment $\mathrm{C}(12.0$ $\mathrm{nmol} / \mathrm{L}$ ) at the beginning of the rearing period, which increased up to $13.9 \mathrm{nmol} / \mathrm{L}$ at the end of the rearing period. Meanwhile, treatment $\mathrm{D}$ had the highest cortisol level $(10.5 \mathrm{nmol} / \mathrm{L})$ at the beginning of the rearing, which increased up to $24.0 \mathrm{nmol} / \mathrm{L}$ at the end of the rearing period.

Oxygen consumption test results during the rearing period are presented in Figure 2 and showed increments in oxygen consumption in all of the treatments. The lowest oxygen consumption range, at both beginning and end of the rearing period, occurred in treatment $\mathrm{C}(0.45$ to $0.58 \mathrm{mgO}_{2} / \mathrm{g} / \mathrm{h}$ ), while the lowest was observed in treatment $\mathrm{D}\left(0.50\right.$ to $\left.0.75 \mathrm{mgO}_{2} / \mathrm{g} / \mathrm{h}\right)$. The $\mathrm{OC}$ range in treatments $\mathrm{A}$ and $\mathrm{B}$ ranged from 0.49 to $0.72 \mathrm{mgO}_{2} / \mathrm{g} / \mathrm{h}$ and 0.48 to $0.66 \mathrm{mgO}_{2} / \mathrm{g} / \mathrm{h}$, respectively.

\section{Water quality parameters}

Water quality parameters, such as $\mathrm{pH}$, dissolved oxygen, temperature, salinity, alkalinity, ammonia, nitrite, nitrate, and total suspended solid (TSS) are presented in Table 3.

Water quality parameter that was directly affected as a result of aeration point addition was dissolved oxygen (DO). The DO concentration during the 42 days rearing period was observed to differ among treatments. Treatment $\mathrm{C}$ had a stable DO range $(5.11$ to $5.77 \mathrm{mg} / \mathrm{L})$, while the highest DO fluctuation range was observed in treatment $\mathrm{D}(3.52$ to $6.31 \mathrm{mg} / \mathrm{L})$, which was due to a significant decrease in DO from the beginning up to day 28 of the experiment. Both $\mathrm{A}$ and B treatments had stable DO levels throughout the rearing period (Figure 3 ).

Table 2. Production performance of mud crab Scylla serrata at the end of the rearing period

\begin{tabular}{lcccc}
\hline \multirow{2}{*}{ Production performance parameters } & \multicolumn{4}{c}{ Treatments (aeration points) } \\
\cline { 2 - 5 } & $\mathrm{A}(0)$ & $\mathrm{B}(1)$ & $\mathrm{C}(2)$ & $\mathrm{D}(3)$ \\
\hline Survival rate $(\%)$ & $40.00 \pm 10.00 \mathrm{c}$ & $53.33 \pm 5.77 \mathrm{~b}$ & $63.33 \pm 5.77 \mathrm{a}$ & $20.00 \pm 10.00 \mathrm{~d}$ \\
Absolute growth rate (g/hari) & $0.52 \pm 0.05 \mathrm{bc}$ & $0.66 \pm 0.06 \mathrm{~b}$ & $0.83 \pm 0.03 \mathrm{a}$ & $0.44 \pm 0.01 \mathrm{c}$ \\
Feed conversion ratio (FCR) & $5.2 \pm 0.5 \mathrm{c}$ & $4.3 \pm 0.5 \mathrm{~b}$ & $3.6 \pm 0.2 \mathrm{a}$ & $6.9 \pm 0.6 \mathrm{~d}$ \\
Weight uniformity coefficient $(\%)$ & $15.12 \pm 1.6 \mathrm{bc}$ & $17.86 \pm 1.2 \mathrm{~b}$ & $21.50 \pm 1.3 \mathrm{a}$ & $12.99 \pm 0.5 \mathrm{c}$ \\
\hline
\end{tabular}

Table 3. Water quality parameters of mud crab Scylla serrata rearing containers during the rearing period.

\begin{tabular}{|c|c|c|c|c|c|}
\hline \multirow{2}{*}{ Water quality parameters } & \multicolumn{4}{|c|}{ Treatment (aeration points) } & \multirow{2}{*}{$\begin{array}{l}\text { Optimal range } \\
\text { (FAO, 2011) }\end{array}$} \\
\hline & $\mathrm{A}(0)$ & $\mathrm{B}(1)$ & $\mathrm{C}(2)$ & $\mathrm{D}(3)$ & \\
\hline Dissolevd oxygen (mg/L) & $3.3-3.9$ & $3.7-4.8$ & $5.1-5.7$ & $3.5-6.3$ & $\geq 5$ \\
\hline $\mathrm{pH}$ & $7.1-7.5$ & $7.1-7.7$ & $7.4-7.7$ & $7.1-7.7$ & $7.5-8.5$ \\
\hline Temperature $\left({ }^{\circ} \mathrm{C}\right)$ & $29.2-30.5$ & $29.3-30.1$ & $28.9-30.7$ & $29.2-30.6$ & $25-35$ \\
\hline Salinity $(\mathrm{g} / \mathrm{L})$ & $24.7-25.6$ & $25.2-25.6$ & $24.7-25.7$ & $25.1-25.6$ & $10-25$ \\
\hline Alkalinity $\left(\mathrm{mg} / \mathrm{L} \mathrm{CaCO}_{3}\right)$ & $183.1-187.7$ & $180.6-186.2$ & $173.1-188.1$ & $185.6-188.8$ & $\geq 80$ \\
\hline Ammonia (mg/L) & $0.006-0.020$ & $0.001-0.014$ & $0.002-0.009$ & $0.002-0.025$ & 0.01 \\
\hline Nitrate $(\mathrm{mg} / \mathrm{L})$ & $0.003-0.367$ & $0.002-0.423$ & $0.003-0.334$ & $0.003-0.148$ & $0.1-1$ \\
\hline Nitrite $(\mathrm{mg} / \mathrm{L})$ & $0.001-0.181$ & $0.002-0.173$ & $0.001-0.121$ & $0.001-0.201$ & 0.5 \\
\hline Total Suspended Solid ( $\mathrm{mg} / \mathrm{L}$ ) & $29.0-42.9$ & $29.5-63.3$ & $27.9-96.2$ & $28.9-142.4$ & $\geq 400$ \\
\hline
\end{tabular}




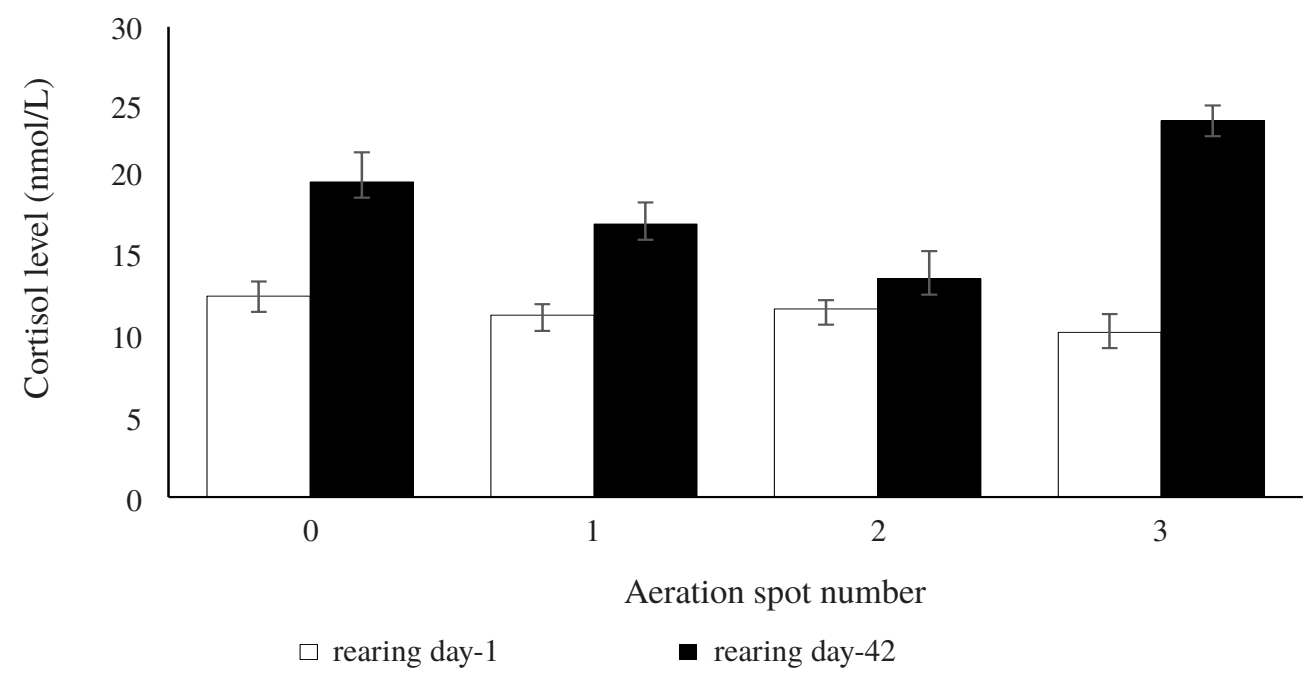

Figure 1. Hemolymph cortisol level of mud crab Scylla serrata in treatments at the beginning and the end of the rearing period.

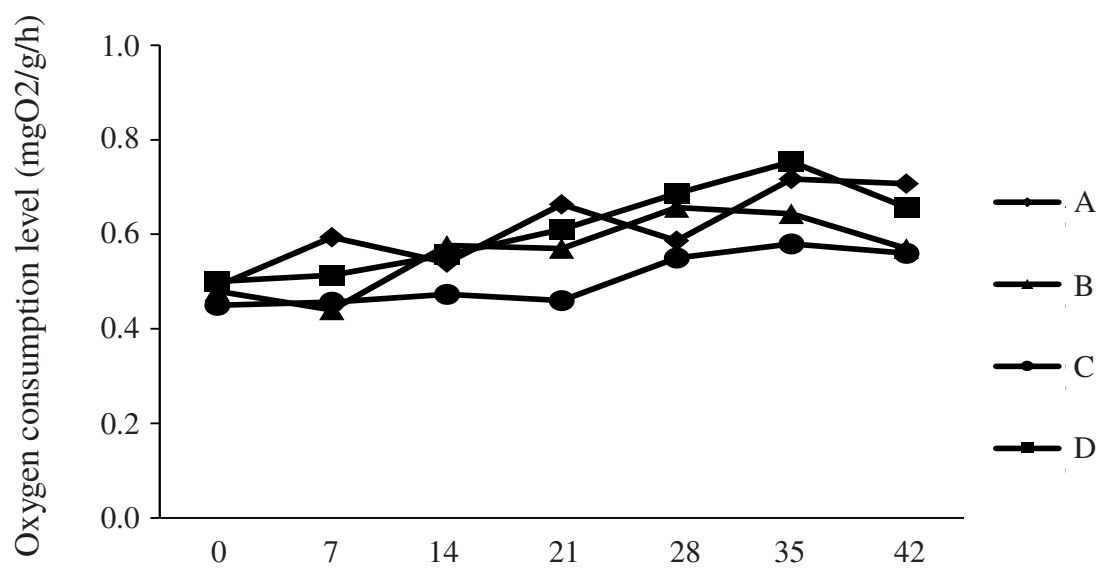

Rearing day

Figure 2. Oxygen consumption level of mud crab Scylla serrata in treatments at the beginning and the end of the rearing period. Note: A (0 aeration spot, initial DO 3.72); B (1, 4.69); C (2, 5.77); D (3, 6.31).

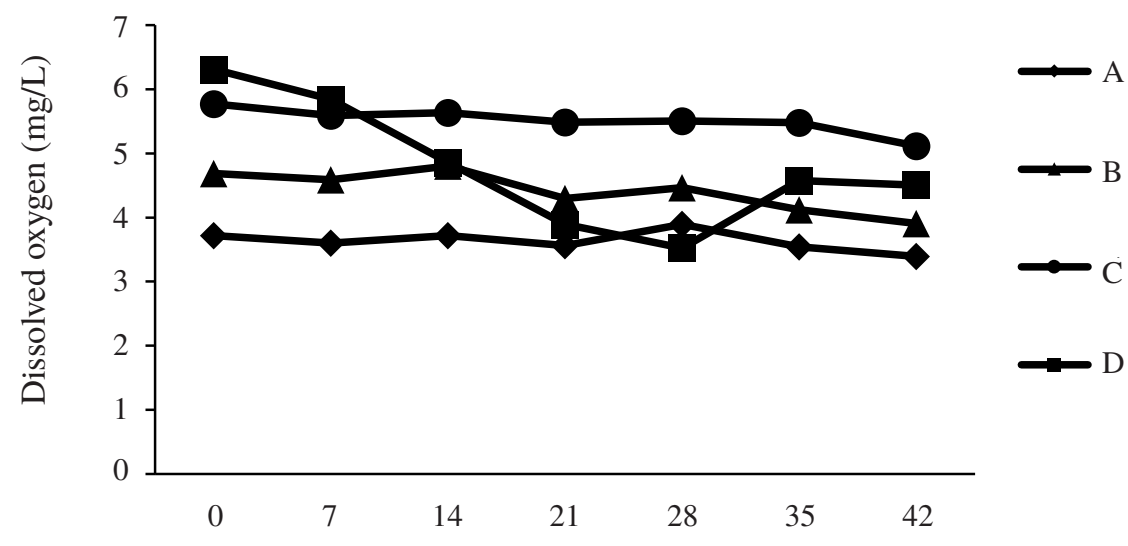

Rearing day

Figure 3. Dissolved oxygen concentration throughout the rearing period. Note: A (0 aeration spot, initial DO 3.72); B $(1,4.69) ; C(2,5.77) ; \mathrm{D}(3,6.31)$. 


\section{Discussion}

The use of recirculating systems throughout the rearing period was aimed at maintaining a stable water quality and reduce water exchange, since water would continuously flow through three filters i.e. physical, chemical, and biological. This recirculating system is based on a filtration process that uses porous medium (Dewi \& Masithoh, 2013) and involves several components, such as physical, chemical and biological filters. The physical filter consisted of cotton and sand and was used to filter the suspended solids out of the rearing water. The smooth nature of the sand was necessary in trapping fine particles such as feces and feed residue in order to filter impurities out of the water body. Zeolite was used as chemical filter and played an important role in absorbing toxic substances such as ammonia and nitrite (Supriyono et al., 2007). Zeolite is referred to as a hydrated alumina silicate mineral that has cavities containing water molecules and cations, which are exchangeable (Nurhidayat et al., 2012). In addition, zeolite is also able to absorb or filter a large number of molecules that are smaller (or have the same size) than the zeolite cavities. Bioball were applied as biological filter, which acted as a medium for bacteria attachment point (nitrifying bacteria), since bacteria take an important part in degrading nitrogenous ammonia into nitrate, which is not toxic for fish (Dewi \& Masithoh, 2013). According Badjoeri et al. (2010) both abundance and activity of bacteria in the sediment may affect the concentration of toxic compounds, which may, in turn, affect the survival and growth of the farmed animal.

Production performance and stress response of S. serrata are directly related to the water quality of the rearing medium. Differences in water quality parameters as a result of aeration points addition in treatments was observed to be the main cause of dissimilarity (among treatments) in terms of production performance and stress response. A few water quality parameters were within the normal range for improving mud crab performance and minimize stress responses during the rearing period and one of them was dissolved oxygen. Dissolved oxygen is a gas that is essential for the survival of aquatic animals (Li et al., 2007), and is obtained through the diffusion from air into the water, mechanical aeration, and photosynthesis of aquatic plants. However, the dissolved oxygen in water could be reduced as a consequence of respiration and decomposition of organic matters in the water body (Dewi \& Masithoh, 2013).
Therefore, the addition of aeration in intensive farming systems is a most in order to prevent oxygen competition between organisms (Paital \& chainy, 2012). In the present study, differences in DO levels were noticed during the 42 days rearing period, and treatment $\mathrm{C}$ had the optimum and stable DO range ( 5.1 to $5.7 \mathrm{mg} / \mathrm{L})$ that provided the best production performance. Meanwhile, DO levels were observed to decrease steadily in treatment $\mathrm{A}, \mathrm{B}$, and $\mathrm{C}$ until the end of the rearing period, while DO dropped sharply in treatment D from the beginning until day-28. The mentioned decrease was due to the size of mud crab, which kept increasing, and decomposition processes that required oxygen (Nurdiani \& Zenc, 2007).

A function that dissolved oxygen (DO) is having is a major influence in the process of aerobic respiration i.e. the breakdown of glucose to produce energy in the form of ATP (NRC, 1977), which is then used by organisms to carry out both metabolism and growth in the body. The key to successfully farming mud crab is in reaching good production performance (Karim, 2007), which consisted of survival rate (SR), absolute growth rate (AGR), feed conversion ratio (FCR), and uniformity coefficient (UC). The survival rate (SR), as the first production performance parameter, displayed the percentage of live and dead fish at the end of the rearing period. It is closely associated to the success of an aquaculture production process, since it determines the amount of feed required and the biomass to be harvested at the end of the rearing period. The analysis of variance test $(\mathrm{P}>0.05)$ results (Table 2) showed significant differences between treatments in terms of survival rate (SR), which reached its highest rate in treatment C (63.3\%), and was due to the good (stable) water quality parameters throughout the rearing period. The stirring effects generated by the aeration points did not affect the feed consumption of mud crab and led to less feed residue production.

Growth is referred to as the process of increasing in physical size such as length and weight and length over a specific period of time (NRC, 1977), and is influenced by internal and external factors (Sartje, 2010). Internal factors consisted of resistance to disease and genetic, while external factors include the environment and the food availability. It was observed that increasing aeration points has significant impacts on treatments in terms of production performances. The production performance parameter that is associated with growth is the 
absolute growth rate (AGR), and treatment $\mathrm{C}$ had the highest AGR $(0.83 \pm 0.03 \mathrm{~g} / \mathrm{crab} /$ day $)$ followed by treatment $\mathrm{B}(0.66 \pm 0.06 \mathrm{~g} / \mathrm{crab} / \mathrm{day})$ and treatment $\mathrm{A}(0.52 \pm 0.05 \mathrm{~g} / \mathrm{crab} / \mathrm{day}$, while treatment D had the lowest AGR $(0.44 \pm 0.01 \mathrm{~g} /$ $\mathrm{crab} /$ day). Production performance data indicated that treatment $\mathrm{C}$ had the best result, which was due to an optimum DO level in the rearing container. Dissolved oxygen was demonstrated to have some very important roles in energy production. For instance, in aerobic respiration, the breakdown of glucose to produce energy in the form of ATP requires the help of oxygen (Badjoeri et al., 2010) and NRC (1977) stated that during aerobic respiration, oxygen acts as a final electron acceptor that produce $\mathrm{H}_{2} \mathrm{O}$ (water) and 38 ATP (energy). In addition, oxygen also affects the budget energy required by $S$. serrata to overcome stress conditions that may result from external factors and an optimum oxygen supply could reduce stress risks of the farmed organism, which may, in turn, decrease oxygen competition between crabs and bacteria. The mentioned competition could cause stress that may affect mud crab growth performance. Bacteria use dissolved oxygen to break down organic matters into simple matters in the rearing medium, and the more organic matter to break down, the more oxygen will be consumed. The quantity of oxygen consumed is also associated to the amount of energy used by mud crab for both maintenance and adaptation to the environment that may affect the amount of stored energy. The energy, which remains from the net energy, will be then used for growth process and gonad maturation (Sousa et al., 2010).

Feed conversion ratio (FCR) is another production parameter, which is reffered to as the amount of feed an animal requires to gain a kilogram of body weight (NRC, 1977). In the present study, treatment $\mathrm{C}$ had the lowest FCR (3.6 \pm 0.2$)$, which was due to the fact that the stirring effects of the two aeration points still left space for the feed to sink to the bottom of the rearing containers. The lower the FCR, the better the feed absorption efficiency, which is then converted into meat or biomass ( $\mathrm{Li}$ et al., 2007). A low FCR would increase the chances of $S$. serrata to reach the feed, which would reduce the accumulation of organic matters in the water.

Reducing organic matters accumulation also affect the stability of the DO supply due to reduction in bacterial activity of breaking down organic matters (Rodriguez et al., 2007). A stable DO may also affect aerobic respiration in $S$. serrata, which could be more optimal, since the portion of energy needed for growth would be greater. Treatment D had the highest FCR (6.9 \pm 0.6$)$, indicating that the given feed was inefficient in generating body mass. The increase in FCR was due the strong stirring effects that took place evenly in all parts of the rearing container, leading to feed that was not properly distributed in the mentioned container. The feed was observed to float on the water surface, which was not efficient in feeding $S$. serrata, since they remained at the bottom of the water. Both A and B treatments had high FCR, 5.2 \pm 0.5 and $4.3 \pm 0.5$ respectively, although the stirring effects of the aeration points was not significant, and the feed could sink to the bottom of the containers. However, the lack of oxygen supply to the aerobic respiration process led to a deficiency in energy production. The budget energy to be used for activities and metabolism also increased, namely to adjust the homeostasis as a response to the environmental conditions, which were not ideal and led to a reduction in energy used for growth (Li et al., 2007).

The coefficient of uniformity (UC) illustrates the degree of variability in mud crab weight at the end of the rearing period, and the higher the $\mathrm{UC}$, the lower the weight uniformity (Aditya et al., 2012). In the present study, treatment $C$ had the highest UC $(21.5 \pm 0.5 \%)$ and the lowest was observed in treatment D $(12.9 \pm 0.5 \%)$, which was due to a feed competition among $S$. serrata that led to diversities in terms of growth. In addition, differences in water quality also led to diversities in terms of stress response. The addition of two aeration points in treatment $\mathrm{C}$ with an optimum DO (ranging between 5.1 to $5.7 \mathrm{mg} / \mathrm{L}$ ) had an impact on the growth rate, which led to a high UC. Treatment A, B, and D had a low water quality stability with high UC compared to treatment $\mathrm{C}$ and was due to a low SR in those treatments, which is likely to increase UC.

Stress is a non-specific discomfort condition that has adverse effects such as decreased immunity, reproductive failure, a decrease in carcass weight, and in extreme case, death of the animal (Ma et al., 2013). It could be caused by both internal and external factors. Internal factors are directly associated with the processes that take place in the fish body being the immunity level and nutrients balance. Meanwhile, external changes that can cause a stress response are due to the environment, water quality, handling, and 
other factors that are extraneous to the fish body. A common parameter used to determine the stress level in fish is the cortisol level in the blood, which when high may affect the fish resistance to diseases. Porchase et al. (2009) stated that the first physiological response of fish (when in a stress condition) in order to keep a good homeostasis is to regulate the (function) hormonal mechanism. In the present study, the results showed that all the treatments experienced an increase in cortisol level at the beginning of the rearing. The lowest cortisol level was observed in treatment C (13.9 $\mathrm{nmol} / \mathrm{L}$ ), indicating that the homeostasis was good at reducing the stress level of $S$. serrata. Meanwhile, the highest cortisol level was noticed in treatment $\mathrm{D}(24 \mathrm{nmol} / \mathrm{L})$ suggesting that the crab experienced a high level of stress. The stress levels are due to poor water quality, which is in accordance with Porchase et al. (2009). They demonstrated that stress is a physiological adaptation to changes resulting from various environmental stressors.

Oxygen consumption rate (OCR) is a parameter that displays the metabolic rate of aquatic organisms (Tseng \& Hwang, 2008). It can also indicate the stress response in fish, since the OCR increase when the fish face environmental stress. The fish would perform activities that would significantly increase the respiration process (Li et al., 2007), which was associated with the use of metabolic budged energy, i.e. the lower the metabolic activity is, the less energy will be used in performing metabolic processes, so the expected budged energy for growth become higher (Watkins et al., 2008). In the present study, treatment $\mathrm{D}$ showed the highest OCR, between 0.50 and $0.75 \mathrm{mgO}_{2} / \mathrm{g} / \mathrm{h}$, compared to other treatments, while the lowest OCR was observed in treatment $\mathrm{C}$ (between 0.45 and $0.58 \mathrm{mgO}_{2} /$ $\mathrm{g} / \mathrm{h}$ ). The low OCR in treatment $\mathrm{C}$ indicated that the environment was optimum in supporting the growth performance of mud crab that could regulate metabolic activities without disturbing both growth and reproductive activities.

\section{CONCLUSION}

The treatment that best support the mud crab Scylla serrata production performances is the treatment $\mathrm{C}$ with two aeration points and a dissolved oxygen (DO) between 5.11 to 5.77 $\mathrm{mg} / \mathrm{L}$. It also had a survival rate (SR) of $63.33 \pm 5$, $77 \%$ and an absolute growth rate (AGR) of $0.83 \pm 0.03 \mathrm{~g} / \mathrm{crab} / \mathrm{day}$.

\section{REFERENCES}

Aditya BP, Sunaryo, Djunaedi A. 2012. Pemberian pelet dengan ukuran berbeda terhadap pertumbuhan kepiting bakau Scylla serrata Forsskal, 1775. Journal of Marine Research 1: 171-177.

Badjoeri M, Hastuti YP, Widiyanto T, Rusmana I. 2010. Kelimpahan bakteri penghasil senyawa ammonium dan nitrit pada sedimen tambak sistem semi intensif. Limnotek 17: 102-111.

Blaxhall PC, Daysley KW. 1973. Routine haematological methods for use with fish blood. Journal Fish Biology 5: 577-581.

Dewi YS, Masithoh M. 2013. Efektivitas teknik biofiltrasi dengan media bio-ball terhadap penurunan kadar nitrogen total. Jurnal Limit's 9: 45-53.

[FAO]. Food and Agriculture Organization. 2011. The State of Word Fisheries and Aquaculture. Rome (IT): FAO.

Goddard S. 1996. Feed Management in Intensive Aquaculture. New York (US): Chapman and Hall.

Hastuti YP, Nadeak H, Affandi R, Faturrohman K. 2016. Optimum $\mathrm{pH}$ determination for mangrove crab Scylla serrata growth in controlled containers. Jurnal Akuakultur Indonesia 15: 24-37.

Hastuti YP, Affandi R, Safrina MD, Faturrohman K, Nurussalam W. 2013. Optimum salinity for growth of mangrove crab Scylla serrata seed in recirculation systems. Jurnal Akuakultur Indonesia 14: 50-57.

Karim MY. 2007. The effect of osmotic at various medium salinity on vitality of female mud crab Scylla olivacea. Jurnal Protein 14: 88-93.

Li E, Chen L, Zeng C, Chen X, Yu N, Lai Q, Qin JG. 2007. Growth, body composition, respiration and ambient ammonia nitrogen tolerance of the juvenile white shrimp Litopenaeus vannamei at different salinities. Aquaculture Research 265: 385-390.

Liao IC, Huang HJ. 1975. Studies on the respiration of economic prawns in Taiwan. I. Oxygen consumption and lethal dissolved oxygen of egg up to young prawn of Penaeus monodon Fab. Journal Fisheries Soc. Taiwan. 4: 33-50.

Ma YC, Yang YJ, Wang GL. 2013. Effects of salinity challenge on the immune factors of Scylla serrata. Acta Agriculturae Zhejiangensis 22: 479-484.

Ministry of Marine Affairs and Fisheries Republic 
of Indonesia. 2010. Sembilan komoditas perikanan jadi unggulan. www.kkp.go.id [10 Juli 2015].

[NRC] National Research Council. 1977. Nutrient Requirement of Warmwater Fishes and Shelfishes: revised ed. Washinton D.C: National Academy Press.

Nurdiani R, Zeng C. 2007. Effects of temperature and salinity on the survival and development of mud crab Scylla serrata Forsskål larvae. Aquaculture Research 38: 1.529-1.538.

Nurhidayat, Nirmala K, Djokosetyanto D. 2012. Biofilter performance effectiveness on water quality, growth performance and survival rate improvement of red rainbow fish Glossolepis incisus Weber reared in recycled water system. Jurnal Riset Akuakultur 7: 89-96.

Paital B, Chainy GBN. 2012. Biology and conservation of the genus Scylla in India subcontinent. Environmental Biology 33: 871-879.

Porchase MM, Cordova LRM, Enriquez RR. 2009. Cortisol and glucose reliable indicator of fish. Pan-American Journal of Aquatic Science 4: 157-178.

Rodriguez EM, Parado-Estepa FD, Quinitio ET. 2007. Extension of nursery culture of Scylla serrata Forsskal juveniles in net cages and ponds. Aquaculture Research 38: 1.588-1.592.

Sartje L. 2010. Osmoregulation in aquatic animals. Jurnal Perikanan dan Kelautan 6:
46-50.

Siahainenia L. 2009. The suitable area analysis of small island for marine ecotourism used of south morotai and South-West Morotai District, North Maluku Province. Journal of Marine Research 8: 103-110.

Sousa T, Domingos T, Poggiale JC, Kooijman. 2010. Dynamic energy budget theory restores coherence in biology. Biological Sciences 365: 3.413-3.428.

Steel RGH, Torrie JH. 1993. Prinsip dan Prosedur Statistika. Jakarta (ID): PT Gramedia Pustaka Utama.

Suprapto D, Widowati I, Yudiati E, Subandiyono. 2014. Growth of mangrove crab Scylla serrata the given different types of feed. Jurnal Ilmu Kelautan 19: 202-210.

Supriyono E, Supendi A, Nirmala K. 2007. The use of zeolit and activated carbon on packing system of Corydoras aenus. Jurnal Akuakultur Indonesia 6: 135-145.

Tseng YC, Hwang PP. 2008. Some insights into energy metabolism for osmoregulation in fish. Comparative Biochemistry and Physiology Part C: Toxicology and Pharmacology 148: 419-429.

Watkins D, Cooperstein SJ, Lazarow A. 2008. Effect of alloxan on permeability of pancreatic islet tissue in vitro. American Journal of Physiology 207: 436-440. 